\title{
The Application of International Law in Macedonia
}

\author{
Marija Risteska, PhD*
}

Kristina Miševa, LL.M.**

\section{Introduction}

The concept of an international society exists

when a group of states, conscious of certain common values, form a society in the sense that they conceive themselves to be bound by a common set of rules in their relations with one another, and share in the working of common institutions. (Bull, 1995:13)

This concept emphasises the importance of principles of international order, such as state sovereignty and non-intervention, but also acknowledges the commitment of states in protecting values such as justice, free trade and human rights. The theory recognises that there is a conflict between the order provided by states and various aspirations for justice. However, scholars take two different positions on the issue of resolving this tension: the pluralist and the solidarist view.

Pluralists argue that order is always prior to justice, and that justice is only possible within the context of order, but never at the price of it. Solidarists, in contrast, look at the possibility of overcoming this conflict by recognising the mutual interdependence of the two concepts. Their main focus is on individuals as the principal holders of rights and duties in international relations and the realisation of individual justice.

\footnotetext{
* Assistant Professor at the Faculty of Political Science and Diplomacy, FON University in Skopje; Executive Director of the Centre for Research and Policy-making .

${ }^{* *}$ Assistant at the Faculty of Law, Goce Delhev University in Shtip.
} 